\title{
Dan Brunton steps down from the Ottawa Field Naturalists' Club Publications Committee after many years of service
}

Dan Brunton, Honourary Member of the Ottawa Field-Naturalists' Club (OFNC; Canadian FieldNaturalist 124: 183-184), has been a long-standing and valued member of the OFNC Publications Committee, including serving in the role of committee Chair from 2011 to 2014. Dan has been a longtime champion of the Club's role in disseminating knowledge to the community, and is a passionate supporter of the Club's publications, Trail \& Landscape (T\&L) and The Canadian Field-Naturalist (CFN). His enthusiasm for club activities and deep knowledge of the history of the OFNC and its publications were among his many valuable contributions as a member of the Publications Committee. Dan has also worked to raise awareness of the significant contributions of Canada's field naturalists, and he played a key role in the development of CFN's "Great Canadian
Field-Naturalists" initiative, designed to formally recognize individuals who have made significant contributions to our knowledge of natural history in Canada (Canadian Field-Naturalist 131: 280-283).

In addition to his contributions to the OFNC Publications Committee, Dan is an active contributor to T\&L and CFN, writing and reviewing research articles, reviewing books, and crafting tributes.

Dan stepped down from the OFNC Publications Committee in early 2021. We thank Dan for his years of exemplary service to the Publications Committee. He will be missed at our OFNC Publications Committee meetings. However, we look forward to his future contributions to both T\&L and CFN.

Amanda E. Martin OFNC Publications Committee

(C) The author. This work is freely available under the Creative Commons Attribution 4.0 International license (CC BY 4.0). 